\title{
Tellurium biogeochemistry in the world's richest tellurium hotspot
}

OWEN MiSSEN ${ }^{1, *}$, JoËL BRUGGER $^{1}$, STUART MILlS $^{2}$, BARBARA ETSCHMANN ${ }^{1}$, RAHUL RAM ${ }^{1}$ \& JEREMIAH SHUSTER ${ }^{3,4}$

${ }^{1}$ School of Earth, Atmosphere and Environment, 9 Rainforest Walk, Monash University, Clayton 3800, Victoria, Australia (*correspondance, omissen@museum.vic.gov.au)

${ }^{2}$ Geosciences, Museums Victoria, GPO Box 666, Melbourne 3001, Victoria, Australia; smills@museum.vic.gov.au

${ }^{3}$ School of Biological Sciences, The University of Adelaide, Adelaide, SA 5005, Australia

${ }^{4}$ CSIRO Land and Water, Contaminant Chemistry and Ecotoxicology, PMB2, Glen Osmond, SA 5064, Australia

Tellurium (Te) biogeochemistry research remains in its infancy, with most studies focusing on laboratory-based research rather than field-based studies. As a chalcogen with multiple oxidation states and varying solubilities, we expect to see complex and metal-resistant microbiomes in regions of Te-enrichment. This phenomena has been observed with other rare metals $(\mathrm{Au}$ and $\mathrm{Pt})$ and metalloids $(\mathrm{Se})$ that, when solubilised, are cytotoxic. Tellurium is an emerging critical material with growing industrial applications such as use in solar cells. As such, mining of Te-bearing base- or preciousmetal deposits has become more extensive and has resulted in increased levels of anthropogenic Te in the environment. My research focuses on in-situ Te-enrichment surrounding Terich outcrops, i.e., natural $\mathrm{Te}$ contamination. At the Moctezuma (Northern Mexico) Te-Au Tertiary epithermal deposit, elemental $\mathrm{Te}$ is the main ore mineral. Surrounding the deposit, Te concentrations in soils exceed $0.1 \mathrm{wt} \%$, indicating extreme levels of Te-enrichment. Our study is the first to perform a holistic field-study of the mineralogy and (bio)geochemistry at Moctezuma, and compare this with other historic $\mathrm{Au} / \mathrm{Te}$-rich mines in North America that also display only Te-enrichment in surrounding soils. Additionally, Te-bearing minerals from Moctezuma show preliminary evidence of alteration, which could be attributed to microbial activity. Specifically, the structure and chemistry of nanometre-scale textures suggest that tellurium biogeochemical cycling, i.e., Te dissolution and subseqent reprecipitation, is occuring within localised microenvironments. Our field site is an ideal location to better understand $\mathrm{Te}$ behaviour in near-surface environments relative to betterstudied tailings piles. This research forms a step towards a better understanding of the full Te biogeochemical cycle, which remains decidedly limited.

Keywords: tellurium, biogeochemistry, elemental cycling 